\title{
Research on Determinants of Graduates' Employability
}

Yuxin Gao ${ }^{1}$, Assoc Prof Dr. Janaka Low ${ }^{2}$

${ }^{1}$ Weinan Vocational \& Technical College Weinan province 714026

${ }^{2}$ Malaysia University of Science and TechnologyMalaysia Kuala Lumpur 47810

Abstract: Although the opportunity for graduates to obtain first-time employment is affected by many factors, employability is one of the most important factors. This study summarizes the related concepts of graduates' employability from the literature, and summarizes the influencing factors of graduates' employability.

Keywords: Graduates; Employability

\section{Introduction}

All students, regardless of geography, achievement, major or learning style, should enjoy fair opportunities to improve their employability and successfully transition and manage their careers (Higher Education Academy, 2016). In the job market, due to the gap between the skills of job seekers and the skills required for the job, employers are more concerned about whether they can obtain a labor force that meets their needs directly or through short-term training. The ultimate goal of higher education is to enable students to master more professional skills and find jobs smoothly (Suskie, 2018).

\section{Literature review}

Despite the annual increase in the number of graduates, there is still an "employment gap" in the job market. With the continuous change of the working environment, more emphasis is placed on the application and innovation of skills, employers also put forward requirements for graduates to have qualities other than degrees, and these abilities are the key factors that determine whether graduates can stand out in the job search.

Some researchers considered that employability is the individual's perception of the possibility of getting a new job, the dimension of employability can define perceived skills, experience, network, personal characteristics and labor market knowledge.

Moir (2010) pointed out that the employability of graduates depends not only on the content of the knowledge they have mastered, but also on the qualities they have acquired in the course of learning based on their personal experience. These qualities are the key to their contribution in a developing society, enabling them to adapt to the changing environment and complete their work across areas of knowledge. Similarly, Knight and Yorke (2010) believed that employability is made up of personal qualities, different skills and subjective understanding.

Rothwell and Rothwell (2017) concluded the employability of graduates is affected by five factors. First of all, employability is affected by the brand or reputation of universities, and there is strong evidence that large-scale graduate recruiters only target universities within a certain range. The next step is that individual ambitions for future success and confidence in their skills will also affect the employability of graduates. At the same time, the audience and development trends in the field of personal research will also have an impact on employability, and finally the situation of the external labor market.

Copyright (c) 2020 Yuxin Gao et al.

doi: 10.18282/le.v9i7.1487

This is an open-access article distributed under the terms of the Creative Commons Attribution Non-Commercial License

(http://creativecommons.org/licenses/by-nc/4.0/), which permits unrestricted non-commercial use, distribution, and reproduction in any medium, provided the original work is properly cited. 


\section{Conclusion}

Under the influence of different factors, such as society, economy, politics, education and so on, the factors that affect the employability are also different. Therefore, scholars need to constantly explore the factors affecting employability from different angles, and finally achieve the goal that the direction of higher education institutions to cultivate students' employability is consistent with the needs of the labor market.

\section{References}

1. Higher Education Academy. (2016). Framework for embedding employability in higher education. www.heacademy. ac.uk/frameworks-toolkits/toolkits

2. Knight, P., \& Yorke, M. (2010). Employability and Good Learning in Higher Education. Teaching in Higher Education, 8(1), 3-16.

3. Moir, J. (2010). First things first: the first year in Scottish higher education. In: Citeseer.

4. Rothwell, A., \& Rothwell, F. (2017). Graduate employability: A critical oversight. In Graduate employability in context (pp. 41-63): Springer.

5. Suskie, L. (2018). Assessing student learning: A common sense guide: John Wiley \& Sons. 